\title{
URGENSI GOOD WILL PEMERINTAH DALAM PEMBENTUKAN UNDANG - UNDANG YANG BAIK
}

\author{
Harmono dan Iis Isnaeni Nurwanty \\ Universitas Swadaya Gunung Jati, Cirebon \\ Universitas Gadjah Mada Yogyakarta, Indonesia \\ Email: mashar.crb@gmail.com dan iis.isnaeni.nurwanty@live.de
}

\section{Abstract}

The journey of legal politics in Indonesia has experienced so many reforms that can be felt. The various contents of the formation of laws and regulations influenced by various aspects are now emerging. The formation of a good government regulation should refer to Law Number 12 Year 2011 concerning the Establishment of Legislation. Hopefully the purpose of this research can be used as a consideration in the formation of legislation. In the end the overall solution in society requires rules that are made with good intentions and in accordance with the existing provisions. The research method in this paper refers to a normative juridical research method, namely researching and analyzing several laws and regulations in 2020 whether they are in accordance with Law Number 12 of 2011. Legislation is a shield and is a legal certainty that will be obtained by society and as maintainers of order in a country.

Keywords: political law; society; formation of legislation - invitation

\begin{abstract}
Abstrak
Perjalanan politik hukum di Indonesia, telah mengalami begitu banyak pembaharuan yang begitu terasa. Berbagai macam isi dari pembentukan peraturan perundang-undangan dipengaruhi oleh berbagai aspek kini kian muncul ke permukaan. Pembentukan peraturan pemerintah yang baik harusnya mengacu kepada UU Nomor 12 Tahun 2011 tentang Peraturan Pembentukan Perundangundangan. Tujuan dari penelitian ini semoga bisa dijadikan sebagai salah satu pertimbangan dalam pembentukan perundangan. Pada akhirnya keseluruhan solusi di masyarakat membutuhkan aturan yang di buat dengan niat baik dan sesuai dengan ketentuan yang ada. Metode penelitian dalam tulisan ini mengacu kepada metode penelitian yang bersifat yuridis normatif, yakni meneliti serta menganalisis beberapa aturan perundang-undangan di tahun 2020 apakah sudah sesuai dengan UU Nomor 12 Tahun 2011. Peraturan perundang-undangan merupakan tameng serta merupakan kepastian hukum yang akan didapatkan oleh masyarakat dan sebagai pemelihara ketertiban dalam suatu negara.
\end{abstract}

Kata kunci: politik hukum; masyarakat; pembentukan peraturan perundang-undangan 
Coresponden Author

Email: mashar.crb@gmail.com

Artikel dengan akses terbuka dibawah lisensi

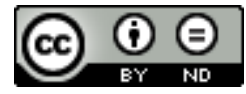

\section{Pendahuluan}

Pembukaan UUD 1945 dan Pancasila telah ditetapkan sebagai grundnorm ataupun rechtsidee dalam setiap pelaksanaan setiap aturan di Indonesia. Oleh karena itu kebijakan pembaharuan yang tidak relevan dan menyinggung kepada dasar penentu penyelenggaraan negara yang menjadi arah kebijakan pembangunan hukum, yaitu Pancasila dapat diartikan bersifat parsial sebab masih kurang melihat sisi pembangunan hukum Indonesia secara integral. Sebagai negara hukum yang berprinsip demokrasi, maka dalam pelaksanaan negara, Indonesia juga secara langsung harus menyelenggarakan pemerintahannya harus berprinsip pada demokratis. (Marwan, 2013) dalam bukunya menuliskan bahwa Bangsa Indonesia akan membangun tatanan kehidupan bersama dalam wadah negara Indonesia yang demokratis dan didasarkan pada aturan hukum, artinya, bangsa Indonesia akan meletakkan prinsip demokrasi dan prinsip hukum sebagai suatu sinergi yang saling bersimbiose-mutualistik dalam mewujudkan adanya national legal order yang demokratis dalam negara. Pembangunan adalah karya terstruktur yang mempunyai implikasi luas terhadap kualitas hidup manusia. Hal ini disebabkan oleh kontruksi pembangunan disusun berdasakan serangkaian aktivitas yang telah direncanakan untuk memajukan kondisi hidup manusia. Penganalogian ini menyiratkan bahwa melalui karya pembangunan yang terstrukturdi dalam berbagai bidang kehidupan yang dilakukan selama ini, telah menjadi pengantar untuk bangsa Indonesia memasuki era baru yang memiliki berbagai konsekuensi. Pembangunan yang melihat kearah kesetaraan sebagai bagian dari kesejahteraan sosial juga tak bisa terpisahkan dari pembangunan nasional, juga mengambil peran aktif dalam meningkatkan kualitas hidup bangsa Indonesia.

Raharjo berpendapat bahwa Pembentukan undang-undang adalah bagian dari aktivitas dalam mengatur masyarakat yang terdiri dari atas gabungan individu-individu manusia dengan segala dimensinya (Rahardjo, 1998) (Suriadinata, 2019), Eddyono menjelaskan jika suatu peraturan perundang-undangan yang baik adalah peraturan yang menceritakan kehendak masyarakat dan paling mensejahterakan masyarakat itu sendiri (Eddyono, 2020) (Ilhami, 2020), menurut Soejito dalam hal ini keterlibatan banyak pihak sangatlah diperlukan, agar tercipta suatu aturan yang memang baik sehingga merancang dan membentuk undang-undang yang dapat diterima masyarakat luas merupakan suatu pekerjaan yang sulit (Soejito, 1993) (Astomo, 2016). Menurut penulis sulit dalam hal ini dimaksudkan karena suatu aturan dapat membunuh ataupun dapat menyelamatkan nyawa, kata membunuh dan menyelamatkan diartikan bahwa suatu aturan mampu mengatur begitu dalam terkait kehidupan manusia. Kesulitan ini terletak pada kenyataan bahwa kegiatan pembentukan undang-undang adalah suatu bentuk komunikasi antara lembaga yang menetapkan yaitu pemegang kekuasaan legislatif 
dengan rakyat dalam suatu negara, Cotte berpendapat terkait hal ini juga diperlukan begitu banyak partisipasi agar suatu aturan dapat terbentuk dengan baik (Cotte, 1991) (Karina, 2019). Seperti kita semua ketahui bahwa setiap aktivitas kehidupan manusia pasti tidak akan terlepas dari aturan hukum. Pada peraturan perundangan, hukum diidentikan sebagai hubungan yang mengatur antara warganya dengan negara atau dapat dikategorikan bahwa hukum bersifat umum. Pembuatan peraturan perundangan umumnya dibuat dan digagas berdasarkan kepada urgensinya, dalam hal ini dibuat khususnya untuk mengindari konflik yang mungkin terjadi, adanya peraturan yang menjadi batasan membuat suatu negara menjadi tenteram dan jelas. Kenyataannya yang terjadi di Indonesia saat ini, aturan perundang-undangan di dasari oleh pengaruh politik yang ada di dalam legislasi, sehingga produk hukum yang dihasilkan tidak memuat apa yang menjadi landasan pentingnya suatu aturan dibuat, bahkan tidak jarang terjadi banyak sekali pasal-pasal dalam peraturan yang sudah di pesan dan dititip untuk diundangkan, untuk itu dalam penulisan ini dibahas beberapa aturan perundangan yang menuai problematika pada tahun 2020 baik yang masih berupa rancangan maupun yang telah diundangkan sebagai bahan kajian bagaimana sebaiknya suatu aturan perundangan di bentuk, serta agar diketahui permasalahan apa yang ada di dalam pembentukan perundangan pada tahun 2020 dan bagaimana sebetulnya arti goodwill dalam pembentukan suatu aturan perundangan.

\section{Metode Penelitian}

Pendekatan yang digunakan dalam melakukan penelitian artikel ini dilaksanakan berdasarkan metode yuridis normatif, yakni penulis menganalisis beberapa peraturan perundang-undangan yang dikeluarkan pada tahun 2020 apakah sudah sesuai dengan ketentuan UU No 12/2011 tentang Pembentukan Peraturan Perundang-undangan atau belum kemudian bagaimana politik hukum pembentukan peraturan perundang-undangan tersebut, apakah sudah sesuai dengan pembentukan peraturan perundang-undangan yang baik atau belum.

\section{Hasil dan Pembahasan}

Hasil analisis peraturan perundang-undangan yang di bentuk di tahun 2020 dapat diambil beberapa aturan yang telah diundangkan. Contoh beberapa peraturan yang masuk ke dalam prolegnas prioritas 2020. Pada prolegnas tahun 2020 terdapat 50 RUU yang dianggap menjadi prioritas untuk dibahas dan disahkan di tahun 2020, diantaranya:

\section{Selama tahun 2020 hanya ada 3 RUU yang disahkan oleh pemerintah, diantaranya:}

a. RUU tentang perubahan atas UU No 4/2009 Tentang Pertambangan Mineral dan Batubara

Proses bembentukan UU No 4/2009 Tentang Pertambangan Mineral dan Batubara memiliki permasalahan ketika dalam proses pembahasan, pada tahap presiden menunjuk perwakilan wakil pemerintah untuk ikut andil dalam 
pembahasan yakni dalam hal ini beberapa Menteri terkait sumber daya alam, namun yang menjadi rancu dalam surat penunjukan yang dikeluarkan Presiden tersebut tidak disertai lampiran Daftar Inventarisasi Masalah (DIM) (DPR, K7RJ-20200515-10312101462:5) RUU Minerba dari Pemerintah, secara pembentukan peraturan perundangan hal ini dapat dikategorikan sebagai suatu permasalahan, seperti pernah dibahas oleh salah satu dosen saat perkuliahan, beliau menjelaskan bahwa surat penunjukan yang dikeluarkan presiden bukan semata - mata hanya sebuah formalitas yang harus dipenuhi, namun dalam surat itu hendaknya mendelegasikan maksud apa yang presiden inginkan dan dalam surat itu mengandung arah politik hukum apa yang harus dipegang dan harus dibuang, karena surat itu merupakan wakil dari presiden itu sendiri dalam keikutsertaannya membuat suatu aturan yang akan mempengaruhi kehidupan rakyatnya.

b. RUU tentang perubahan atas UU No. 13/1985 tentang Bea Materai,

Pembahasan tentang RUU ini tidak diposting dalam website resmi DPR RI.

c. RUU Cipta Kerja

Urgensi pengesahan ketiga peraturan tersebut sebetulnya tidak terlalu mendesak, namun kenyataannya pemerintah tahun 2020 ini mengesahkan peraturan tersebut, sudut pandang mana yang sebetulnya diambil, hingga saat ini penulis masih belum menemukan jawaban pastinya, selain itu dalam UU 11/2020 tentang Cipta kerja, menuai banyak penolakan dari berbagai kalangan, selain itu banyak sekali aspek-aspek dalam UU cipta kerja yang menimbulkan kontroversi di masyarakat. Pembuatannya yang dinilai sangat cepat membuat uu ini dinilai tidak mempunyai standarisasi peraturan perundangan yang baik, sebab dalam pembuatannya banyak sekali hal-hal yang harus dicermati, misalnya dalam penulisan pasal, banyak kekeliruan typo yang terjadi, sehingga undang undang ini dinilai kacau.

Zainal Arifin Mochtar dalam kuliah politik hukum menjelaskan bahwa seharusnya para pembentuk aturan, khususnya dalam pembentukan perundangan wajib memperhatikan apa yang terkandung di dalam UU 12/2011 Tentang Pembuatan Peraturan Perundangan, perlakuan para pembuat undang-undang harus berhati-hati dalam penyunannya karena pembuatan peraturan, undangundang merupakan sesuatu yang sakral dan harus sangat diperhatikan dengan penuh kehati-hatian.

\section{Rancangan Undang-Undang yang dikeluarkan dari prolegnas:}

Pada tahun 2020 ini kita semua dikejutkan dengan beberapa hal yang dilakukan oleh para anggota dewan yang terhormat dalam pembentukan peraturan perundangan. Seperti hadiah pada umumnya, tidak semua kejutan itu memang baik dan memberikan feedback yang patut diapresiasi, dalam hal ini ada beberapa Rancangan Undang-Undang yang menurut penulis dianggap penting 
dan urgensi untuk dilaksanakan, namun kenyataannya malah justru dikeluarkan dari proglenas.

a. Rancangan Undang-Undang Penghapusan Kekerasan Seksual

Dalam (Butterfield, 2018) pemberitaan jerman disebutkan bahwa Zwei Millionen Frauen und Mädchen werden laut Weltgesundheitsorganisation (WHO) jährlich Opfer von früher Heirat, Kinderprostitution, sexuellen Verstümmelungen und Vergewaltigungen, die in vielen Fällen eine Lebensgefahr darstellen (Süddeutsche Zeitung 04.10.94). Die Sterblichkeitsrate für Mädchen zwischen zehn und vierzehn Jahren, die Kinder zur Welt bringen, ist fünfmal höher als bei Müttern zwischen 20 und 24. Jährlich sterben 70.000 bis 200.000 Frauen an den Folgen von Abtreibungen (je nach Untersuchung). Mehr als 80 Millionen Frauen und Mädchen sind die Genitalien beschnitten (Stoller 1994 und Honey 1994).

WHO mencatat pertahun lebih dari dua juta perempuan dan anak perempuan menjadi korban pernikahan dini, pelacuran anak, mutilasi seksual dan pemerkosaan, yang dalam banyak kasus menimbulkan bahaya yang mematikan

Penulis berpendapat bahwa RUU ini seharusnya masuk ke dalam kategori prolegnas prioritas DPR di tahun ini mengingat bahwa telah banyak konferensi internasional dan berita - berita Internasional maupun lokal yang mengatakan bahwa perempuan dan anak memerlukan perlindungan yang sangat khusus, mengingat kedudukannya yang sangat rentan menjadi korban dan dalam kekerasan seksual, perempuan dan anaklah yang biasanya target utamanya. Women shall be especially protected against any attack on their honour, in particular against rape, enforced prostitution, or any form of indecent assault. A complementary principle to the basic principle is that women must be treated with all consideration due to their sex (de Preux, 2010). Artikel ini memuat tentang berapa pentingnya perlindungan bagi perempuan, penegasan bahwa perempuan harus dilindungi secara khusus merupakan suatu hal mendasar yang patut pemerintah tindaklanjuti secara khusus dari serangan apa pun terhadap kehormatan mereka, khususnya terhadap pemerkosaan, pelacuran yang dipaksakan, atau segala bentuk serangan tidak senonoh. Prinsip yang melengkapi prinsip dasarnya adalah bahwa perempuan harus diperlakukan dengan segala pertimbangan karena jenis kelaminnya.

RUU PKS telah terus menerus mengalami penundaan, padahal secara urgensi justru RUU ini sangat dibutuhkan oleh masyarakat, jika di bandingkan dengan UU lain yang ada di dunia, misalnya ada statement yang mengatakan bahwa ruu ini akan mendiskrimasi pihak laki-laki, menurut pendapat penulis hal itu sangatlah tidak tepat, mengingat bahwa hanya ada beberapa jenis dasar ruu saja, jika ruu pks dianggap diskriminasi dan membuat laki-laki insecure, kita harus melirik bahkan di sexual offences act 2003 Inggris, pengkategorian kekerasan seksual dibuat lebih details dan menyeluruh lagi, untuk itu mengapa 
sebagian anggota dewan khsusunya laki-laki terkesan ketakutan akan aturan ini, padahal ini merupaka aturan yang sangat baik untuk segera ditindaklanjuti di Indonesia, mengingat bahwa kita harus melihat bahwa jika harus dibandingkan dengan apa yang ada di Inggris ruu ini belum ada apa-apanya namun walau demikian dan belum lengkap jika dibandingkan, kita bisa tetap mengatakan bahwa RUU PKS ini sudah masuk dalam kategori baik dan apabila kita tetap berpegang teguh pada undang-undang sebelumnya, saya fikir hal itu tidaklah betul mengingat jika di depan mata sudah ada hal baik, mengapa tidak dilanjutkan tahapanya? Selain itu pemerintah selalu mengagung-agungkan bahwa kedaulatan berada di tangan rakyat, namun mengapa hingga saat ini aspirasi rakyat khususnya perempuan tidak diseriusi oleh pemerintah?

Hal tersebut patut menjadi pertanyaan selanjutnya tentang bagaimana sebetulnya sistem penyusunan peraturan perundangan yang Indonesia terapkan.

b. Rancangan Undang-Undang Pekerja Rumah Tangga

RUU ini sedikit unik, setelah sebelumnya membutuhkan selama 16 tahun merangkak untuk masuk ke dalam prolegnas, setelah sekian lama akhirnya masuk ke dalam prolegnas prioritas di 2020 namun sayangnya, pada bulan Juni 2020 RUU ini lagi-lagi malah menjadi salah satu dari 16 RUU yang dikeluarkan dari prolegnas, urgensi ruu ini juga sama halnya dengan RUU PKS diatas, namun sayangnya perjuangan bertahun-tahun kini terhempas sudah, tetapi lucunya di bulan desember ini, RUU tersebut masuk kembali ke dalam usulan prolegnass prioritas di tahun 2020, artinya kita bisa melihat bahwa para perwakilan rakyat dalam memperlakukan RUU dapat diibaratkan seperti sedang bermain-main saja, jika memang RUU ini dianggap penting, mengapa di bulan Juni 2020 harus dikeluarkan? Begitu pula jika sebaliknya, jika ia tidak penting, mengapa ia kembali dimasukan dalam prolegnas? Hal tersebut menurut penulis dipandang sebagai hal yang sia-sia dilakukan oleh para wakil rakyat, memang betul bahwa mereka memegang kekuasaan atas pemilihan mana yang termasuk kedalam prolegnas prioritas dan bukan, namun secara tersirat hal ini dapat dipandang membuang waktu untuk sesuatu yang tidak konsisten

c. Rancangan Undang-Undang Sistem Kesehatan Nasional

Selain RUU diatas, menurut penulis RUU Sistem Kesehatan Nasional juga merupakan RUU yang seharusnya diseriusi untuk dilaksanakan pembahasan oleh pemerintah, alasannya sebab telah kita sepakati bahwa di tahun ini, dunia digegerkan oleh pandemic covid 19. Pandemic covid 19 mendorong pemerintah secara tidak langsung harus berfokus untuk melaksanakan penanganan dan upaya peningkatan serta pemulihan Kesehatan bagi warganya, untuk itu disini sistem kesehatan nasional harus diperhatikan, mengingat banyak tahapan masyarakat untuk melaksanakan pemeriksaan kesehatan, disisi lain juga, kita telah mengetahui bahwa selama ini sistem 
jaminan kesehatan masyarakat yang diberikan oleh pemerintah pelaksanaannya belum efektif dan masih menuai banyak permasalahan, untuk itu maka disini pemerintah perlu melaksanakan fungsinya.

d. Rancangan Undang-Undang Kehutanan

Rancangan Undang-Undang Kehutanan ini juga merupakan salah satu rancangan undang-undang yang kemudian ikut dikeluarkan dari proglenas prioritas di tahun ini, padahal kenyataannya menurut penulis seharusnya sebelum pemerintah menetapkan UU No 11/2020, pemerintah haruslah terlebih dahulu menetapkan RUU Kehuatan ini, karena ketika investasi dibuka sebesarbesarnya, akan memberikan imbas kepada kehutanan, dalam hal ini misalkan saja aada investor yang tertarik dalam usaha kelapa sawit, untuk membuka usaha kelapa sawit maka dibutuhkan pembukaan lahan, dalam hal ini pasti akan berlari ke lahan yang ada dihutan, untuk itu perlu dilihat sudah sejauh apa sektor kehutanan dilindungi? Bagaimana dengan hutan konservasi yang bisa menjadi target para pemodal dan izin-izin yang dilakukan selama ini?

e. Rancangan Undang-Undang Pertanahan

Berdasarkan analisis penulis dengan membaca beberapa sumber di internet, diambil kesimpulan bahwa RUU ini juga merupakan RUU yang sangat penting untuk dibahas oleh anggota legislasi, mengingat bahwa telah lama sekali permasalahan pernahan terjadi di Indonesia mulai dari konflik pertanahan, konflik agrarian, pegklaiman lahan.

Pada aturannya, memang betul bahwa penyelenggara negara mempunyai wewenang untuk melahirkan suatu peraturan perundang-undangan yang bertujuan dalam rangka mengubah tatanan dan memperbaiki tertib sosial agar sesuai dengan apa yang negara cita citakan. Pelaksanaan kewenangan itu kemudian dituangkan ke dalam politik hukum. Menurut penulis politik hukum itu sendiri adalah suatu arah pernyataan keinginan suatu negara terkait hukum apa yang ingin berlaku di wilayahnya serta sebagai kompas kearah mana hukum akan dikembangkan dan bermuara. Sehingga dalam pembentukan perundang-undangan sudah pasti ada tujuan apa yang hendak dicapai dari dikeluarkannya peraturan perundangan tersebut, maka dengan sifatnya yang demikian, artinya suatu aturan perundangan pasti akan bermuatan politik, karena suatu aturan perundangan dibuat tidak akan terlepas dari kepentingan politik itu sendiri, akan tetapi tidaklah mutlak demikian bahwa kepentingan politik lebih utama daripada apa yang diinginkan rakyat. Seperti kita ketahui bahwa hukum yang baik merupakan hukum yang lahir melalui kehendak rakyat dan sesuai dengan kebutuhan rakyat. Hukum yang sesuai dengan apa yang rakyat inginkan dan kehendaki, akan otomatis menjawab kebutuhan apa yang memang rakyat inginkan, selain itu rakyat juga akan secara sukarela mematuhi dan melaksanakan hukum tersebut, sebab hukum bukan suatu paksaan dari negara kepadanya.

Arah politik hukum yang dianut oleh pemerintah selama 2020 ini lebih 
terfokus kepada politik hukum yang mengarah kepada kebijakan ekonomi, khususnya investasi, dalam hal ini memang betul salah satu permasalahan yang dihadapi Indonesia sebagai negara berkembang adalah bagaimana cara Indonesia menghadapi pembangunan dan semakin meningkatnya jumlah pengangguran setiap tahunnya, namun selain jumlah pengangguran, harusnya kita patut melihat bagaimana aspirasi dan reaksi rakyat terhadap suatu peraturan perundangan.

Berkaca kepada undang-undang cipta kerja kita bisa melihat, bahwa begitu banyak kontroversi dan aksi protes yang dilakukan rakyat di depan Gedung-gedung anggota dewan di setiap kota, apabila pemerintah lebih peka, seharusnya pemerintah melihat bahwa bukan aturan itu yang masyarakat perlukan saat ini. Kritik terhadap pemerintah terkait pembuatan peraturan perundangan adalah bahwa kita harus belajar memahami bahwa salah satu ciri pembentukan peraturan perundangan yang baik, selain dari bagaimana proses pembentukannya, juga dapat dianalisis melalui ada tidaknya pertentangan yang terjadi. Secara proses pembentukan suatu suatu aturan kiranya dilandaskan pada pemikiran kearah pembentukan peraturan perundang-undangan, secara taat asas, adanya korelasi antara segi materi dan manfaatnya, atau baiknya dari segi daya lakunya harus menjadi perhatian pembentuk peraturan perundangundangan. Ini setidaknya dapat digunakan sebagai parameter bagi lahirnya Peraturan perundangan yang responsive/ populistic untuk itu dalam hal ini perlu adanya rekonstruksi terhadap politik hukum pembentukan suatu peraturan agar peraturan itu bisa menjadi peraturan yang baik.

Menurut Montesquieu menuliskan bahwa terkait dengan peraturan perundang-undangan yang menjadi dasar hukum pengaturan, hal penting harus diperhatikan adalah pembentukan peraturan perundang-undangan (Putra, 2015). Peraturan perundang-undangan yang baik merupakan peraturan perundang-undangan yang pembentukannya didasarkan pada asas-asas pembentukan peraturan perundang-undangan yang baik. Hal ini sesuai dengan pendapat Maria Farida Indrati berpendapat bahwa asas-asas pembentukan peraturan perundang-undangan adalah suatu pedoman atau suatu rambu-rambu dalam pembentukan peraturan perundang-undangan yang baik (Indrati \& Farida, 2007). Attamimi berpendapat bahwa asas-asas umum pembentukan peraturan perundang-undangan yang baik (beginselen van behoorlijke wetgeving) adalah asas hukum yang memberikan pedoman dan bimbingan bagi penuangan isi peraturan ke dalam bentuk dan susunan yang sesuai, bagi penggunaan metoda pembentukan yang tepat, dan mengikuti proses dan prosedur pembentukanya yang telah ditentukan (Attamimi, 1990). Berkaitan dengan dengan asas-asas yang menjadi dasar dalam pembentukan peraturan perundang-undangan yang baik, Van der Vlies telah membagi dalam dua asas, yakni asas-asas formal dan asas-asas materiil dalam asas-asas ini diantaranya terdapat beberapa aspek yang harus diaplikasikan dalam suatu peraturan dan 
tidak dapat dilepaskan (Van der Vlies, 2005).

\section{Kesimpulan}

Lesson learn yang dapat kita petik di tahun 2020 ini berdasarkan kepada hasil analisis beberapa peraturan perundang-undangan yang di bentuk pada tahun 2020, dapat dikatakan bahwa peraturan perundang-undangan di Indonesia di nilai tidak dilaksanakan sesuai dengan aturan yang berlaku serta dalam perumusan peraturan perundangan para pembentuk peraturan perundangan harus kembali berkaca bahwa mereka telah terlalu jauh melangkah dan langkahnya kini sudah terlampau sulit untuk diraih oleh masyarakat, mereka harus mengingat kembali bahwa kekuasaan yang mereka miliki bukanlah seutuhnya milik mereka, melainkan kekuasaaan yang didelegasikan oleh rakyat kepada mereka sebagai wakil rakyat. Pembentukan peraturan perundangan telah diatur dengan baik dalam UU No 11/2012 untuk itu dalam pembuatan peraturan harus mengikuti aturan tersebut, bukan malah dilaksanakan dan dipoles sesuka hati para penguasa saat ini, walaupun memang kenyataannya sudah menjadi sifat dasar manusia, yang apabila ia diberikan kekuasaan, ia akan bertindak sewenang-wenang, namun disinah hukum mempunyai andil untuk mengaturnya agar kembali sesuai jalur yang telah ditentukan dalam hukum.

Arah politik hukum yang lebih mengarah kepada nilai ekonomi menjadikan pembuatan perundangan hanya bersifat bisnis dan akan dilaksanakan jika memang itu akan memberikan keuntungan dalam segi materi sehingga tidak sesuai dengan target yang diinginkan, bahkan kemudian hari tidak menutup kemungkinan akan lahir aturanaturan yang bukannya semakin baik, malah sebaliknya. Kita bisa lihat dalam contoh nyata di UU 11/2020 telah diatur perizinan lingkungan berbasis resiko. Konsep keberlanjutan yang di pakai dalam UU No 32/2009 saja di Indonesia masih menuai berbagai masalah, padahal secara konseptual UU tersebut sudah sangat baik, rasanya terlalu beresiko jika tanpa kajian lebih lanjut dan kesiapan yang matang kemudian Indonesia khususnya, menerapkan konsep perizinan berbasis resiko. Permasalahan lain yang akan menjadi penghambat dalam hal perizinan berbasis resiko juga dapat muncul dari aparat penegak hukumnya, telah diketahui secara umum bahwa isu kelembagaan di Indonesia masih sangat lemah sekali dan tingkat kasus koruspsi di Indonesia masih sangat tinggi, dengan keberadaan pengkonsepan yang belum disiapkan dengan baik, maka kegiatan korupsi dapat menganga bebas. Selain dukungan dari prinsip keberlanjutan yang memang telah di dukung oleh konsep-konsep yang matang, pendekatan berbasis resiko kini dianggap terlalu gegabah mengingat setiap sumber daya alam mempunyai batasnya sendiri, dan jika kita akan berhubungan dengan sumber daya alam dan ekosistemnya harus dilaksanakan berdasarkan kepada prinsip kehati-hatian.

Pemerintah yang dianggap sangat gegabah dalam pembuatan peraturan perundangan dianggap akan membuat negara bukannya semakin baik tapi akan lebih mengacaukan lagi, hal ini di dukung dengan adanya fakta di lapangan yang dapat kita lihat secara nyata, dimulai dari semakin naiknya korupsi di Indonesia, semakin banyaknya jumlah gelandangan, pengangguran dan naiknya tingkat kejahatan 
merupakan salah satu permasalahan yang ditimbulkan oleh aturan yang kurang berfungsi sebagaimana mestinya untuk itu penulis merasa bahwa urgensi kesadaran harus dibentuknya peraturan perundang-undangan sangat diperlukan, selain itu dalam proglegnas tahun depan diharapkan dapat dipilah dan dipilih kembali mana saja Rancangan Undang-Undang yang harus dijadikan prioritas, mengingat bahwa produk hukum tersebut akan memberi imbas yang sangat besar dalam kehidupan, selain itu pemerintah diharapkan dapat mendengar lagi suara hati rakyat, karena rakyatpun ingin yang terbaik untuk negaranya, serta rakyatpun tentu tidak mau imbas yang buruk terjadi pada negaranya, serta arah politik hukum sebaiknya dikembalikan lagi, misalkan kepada anggota-anggota perwakilan rakyat yang memang buta hukum, apa salahnya mereka untuk sekolah lagi fakultas hukum, setelah kita berkaca pada perlakuan perwakilan rakyat dalam pembuatan UU 11/2020 kemarin dapat kita lihat bahwa banyak anggota dewan yang tidak mengerti hukum hingga penulisan bahkan banyak penempatan kata yang salah, serta typo mereka jadikan sebagai suatu hal yang wajar, padahal kenyataannya dalam pembuatan perundangan yang sakral tersebut, hal seperti demikian harusnya tidak terjadi. 


\section{BIBLIOGRAFI}

Astomo, Putera. (2016). Pembentukan Undang-Undang dalam Rangka Pembaharuan Hukum Nasional Di Era Demokrasi. Jurnal Konstitusi, 11(3), 577-599.

Attamimi, A. Hamid S. (1990). Peranan keputusan presiden republik Indonesia dalam penyelenggaraan pemerintahan negara: suatu studi analisis mengenai keputusan presiden yang berfungsi pengaturan dalam kurun waktu Pelita I-Pelita IV.

Butterfield, Hester. (2018). Integration (un) erwünscht?! Emanzipatorische Soziale Arbeit mit ge. Soziale Arbeit Mit Frauen Und Mädchen: Positionsbestimmungen Und Handlungsperspektiven, 1, 202.

Cotte, Pierre Andre. (1991). The Interpretation of Legislation in Canada, Les Editions Yvon Balais. Inc., Quebeec.

de Preux, Jean. (2010). Summary III: Special protection of women and children. International Review of the Red Cross (1961-1997), 25(248), 292-302.

Eddyono, Sri Wiyanti. (2020). Gerakan Advokasi Legislasi Untuk Perlindungan Pekerja Migrant Indonesia (Edisi Pert). Jakarta: Migrant Care.

Ilhami, Nadya. (2020). Upaya Migrant Care dalam Perlindungan Pekerja Migran Indonesia Di Malaysia (2014-2019). Universitas Muhammadiyah Malang.

Indrati, Maria Farida, \& Farida, Maria. (2007). Ilmu Perundang-Undangan, Proses dan Teknik Pembentukannya. Yogyakarta: Kanisius.

Karina, Ratna Eta. (2019). Perlindungan Hukum bagi Advising Bank atas Terjadinya Fraud dalam Transaksi Perdagangan Internasional Menggunakan Letter of Credit. UNS (Sebelas Maret University).

Marwan, Awaludin. (2013). Filsafat Hukum Progresif Sadjipto Rahardjo. Yogyakarta: Thafa Media.

Putra, Muhammad Amin. (2015). Perkembangan Muatan HAM dalam Konstitusi di Indonesia. Fiat Justisia: Jurnal Ilmu Hukum, 9(2).

Rahardjo, Satjipto. (1998). Penyusunan Undang-Undang yang Demokratis. Makalah Dalam Seminar "Mencari Model Ideal Penyusunan Undang-Undang Yang 
Urgensi Good Will Pemerintah dalam Pembentukan Undang-Undang yang Baik

Demokratis Dan Kongres Asosiasi Sosiologi Hukum Indonesia” Fakultas Hukum Universitas Diponegoro Semarang Tanggal, 15-16.

Soejito, Irawan. (1993). Teknik Membuat Undang-Undang (Cetakan Ke). Jakarta: PT. Pradnya Paramita.

Suriadinata, Vincent. (2019). Penyusunan Undang-Undang di Bidang Investasi: Kajian Pembentukan Omnibus Law di Indonesia. Refleksi Hukum: Jurnal Ilmu Hukum, 4(1), 115-132.

Van der Vlies, I. C. (2005). Buku Pegangan Perancang Peraturan Perundang-undangan diterjemahkan oleh Linus Doludjawa. Jakarta Selatan: Direktorat Jenderal Peraturan Perundang-Undangan Kementerian Hukum Dan Hak Asasi Manusia RI. 